\title{
Colibacillosis in lambs is associated to type $I$ heat-stable enterotoxin in a farm in São Paulo State, Brazil
}

\author{
Colibacilose em carneiros é associada à enterotoxina termo-estável do tipo I em uma propriedade rural \\ do estado de São Paulo, Brasil
}

\author{
Annelize Zambon Barbosa Aragão ${ }^{I}$ Marcelo Ananias Teocchi ${ }^{I}$ Maria Clara Duarte Fregolente ${ }^{\mathrm{I}}$ \\ Maria Silvia Viccari Gatti ${ }^{\mathrm{I}}$ Alexandre Vaz Pires ${ }^{\mathrm{II}}$ Tomomasa Yano ${ }^{\mathrm{I}^{*}}$
}

\section{- NOTE -}

\begin{abstract}
Twenty seven (48.2\%) culture supernatants of 56 Escherichia coli isolated from diarrheic lamb feces (7 to 10 days old) in São Paulo State, Brazil, presented positive results to suckling mice assay (fluid accumulation) but none caused cytopathic effects on Vero and $\mathrm{CHO}$ cells, indicating that these strains did not produced LT or VT toxins. PCR assays showed that these $27 \boldsymbol{E}$. coli strains harbored estA, that codifies for STa, but not for stx 1 , stx2 or cnf genes. The positive STa strains were checked for genes that codify for F41, F17 and K99 fimbriae, wich are considered colonization factors in ETEC. Only F17 was detect in two samples (7.4\%). Twelve of 27 STa positive carried hlyA gene and presented hemolytic activity in blood Agar. Presence of rotavirus was not detected among the diarrheic feces. These data suggests that STa must be an important diarrheagenic factor to small ruminants in São Paulo State.
\end{abstract}

Key words: lambs, STa, colibacillosis, Escherichia coli.

\section{RESUMO}

Cinquenta e seis Escherichia coli isoladas de fezes diarreicas de carneiros (7 a 10 dias) no Estado de São Paulo, Brasil, foram avaliadas quando ao acúmulo de fluidos no intestino de camundongos recém-nascidos. Vinte e sete $(48,2 \%)$ das amostras foram positivas para esse ensaio, porém nenhuma das 56 amostras foi capaz de induzir efeitos citopáticos em células Vero e CHO, indicando que não produzem toxinas $L T$ ou VT. Análise por PCR mostrou que estas 27 E. coli foram positivas para estA, que codifica a proteína STa, mas não para os genes stx1, stx2 ou cnf. As amostras positivas para STa foram também analisadas quanto à presença dos genes que codificam as fímbrias F41, F17 e K99, fatores de colonização em ETEC. Somente F17 foi detectada em 2 amostras (7,4\%). Doze das 27 E. coli STa positivas também contêm o gene hlyA e apresentaram atividade hemolítica em Agar sangue. Rotavírus não foi detectado nas fezes desses animais. Em conjunto, esses resultados sugerem que STa é um fator diarreiogênico importante para colibacilose de pequenos ruminantes no Estado de São Paulo.

Palavras-chave: carneiro, STa, colibacilose, Escherichia coli.

Escherichia coli is a commensal microorganism present in mammalian guts and is considered one of the most common etiological agent of diarrhea in both humans and animals. The virulence factors (VF) are responsible for survival and adaptation in a host environment, however there are not conclusive information about the VF involved in colibacillosis pathogenicity. ETEC (enterotoxigenic E. coli) causes diarrhea by means of production of two different toxins: LT (heat-labile enterotoxin) and ST (heat-stable enterotoxin). STa were usually associated with diarrhea in humans, piglets and bovine, while STb were associated with diseases in piglets. SMITH \& HUGGIS (1983) were the first to report the involvement of ETEC in lamb diarrhea cases. In Brazil, VETTORATO et al. (2003) detected STEC (Shiga toxin producing $\boldsymbol{E}$. coli) in healthy sheep feces. Thus, our objective was to evaluate which VF was most important for the lamb colibacillosis in São Paulo State, Brazil.

\footnotetext{
'Departamento de Genética, Evolução e Bioagentes, Instituto de Biologia, Universidade Estadual de Campinas (UNICAMP), 13083-970, Campinas, SP, Brasil. E-mail: tyano@unicamp.br. *Autor para correspondência.

"Universidade de São Paulo (USP), Escola Superior de Agricultura Luiz de Queiroz (ESALQ), Departamento de Zootecnia. Piracicaba, SP, Brasil.
} 
For this study, one strain was isolate of each feces samples, selected from 60 lambs ( 7 to 10 days olds) with diarrhea, on a single farm in Araras, São Paulo State, Brazil. These strains were biochemical identified by EPMMILi-Citrate medium (TOLEDO et al., 1982a,b). Cytotoxicity assays were performed with $\boldsymbol{E}$. coli strains cultured in $10 \mathrm{ml}$ of TSB with shaking at $150 \mathrm{rpm}(\mathrm{New}$ Brunswick Scientific Co) for $18 \mathrm{~h}$ at $37^{\circ} \mathrm{C}$. The culture supernatants were collected after centrifugation and filtered through a $0.22 \mu \mathrm{m}$ filter (Millipore) and applied in cell cultures. Vero (African green monkey kidney) and $\mathrm{CHO}$ (Chinese hamster ovary) cells were cultivated in 96wells plates (TPP) with Eagle's minimum essential medium (MEM, Nutricell) supplemented with 10\% fetal bovine serum, at $10^{4}$ cells per $\mathrm{ml}$. Morphological alterations were observed after 24 and 48 hours, using an inverted microscope (Nikon). Gene amplifications were performed by PCR. The primers used, annealing temperatures and the amplified fragments size are in table 1 . The reactions were heated to $94^{\circ} \mathrm{C}$ in an automated thermal cycler (Mastercycler Gradient, Eppendorf) for $2 \mathrm{~min}$ followed by 30 cycles of denaturation, annealing and extension, followed by a final extension step. The amplicons were visualized into a $0.8 \%$ agarose gel at UV translluminator after staining with ethidium bromide. The STa positive $\boldsymbol{E}$. coli culture supernatants were tested in the suckling mice assays following the methodology described by DEAN et al. (1972). For hemolytic activity, blood Agar plate assay were used at hlyA positive strains. The blood Agar plates were prepared with 5\% sheep erythrocytes for áhaemolysin detection and, for â-haemolysin, the sheep erythrocytes were washed with PBS three times. The strains were cultivated in TSB and plated in the plates. Observations of hemolytic zones around the colonies were made after incubation for $18 \mathrm{~h}$ at $37^{\circ} \mathrm{C}$. E. coli O157:H7 and $\boldsymbol{E}$. coli K-12 were used as positive and negative controls, respectively. Furthermore, fecal suspensions were analyzed for Rotavirus presence. Briefly, the nucleic acids were extracted with phenolchloroform, precipitated with ethanol and analyzed by polyacrylamide gel electrophoresis (PAGE), using 7.5\% slab gels, stained with silver nitrate (HERRING etal., 1982).

Among the 60 isolates, 56 were identified as E. coli. The other 4 samples were not identified because they did not belong to the Enterobacteriaceae family. These 56 strains were evaluated by cytotoxicity assays and did not cause any morphological alterations in Vero and $\mathrm{CHO}$ cells. This suggests that these $56 \boldsymbol{E}$. coli did not produced LT, neither Shiga toxin. In Spain, BLANCO et al. (1996) analyzed 144 E. coli and they observed that only $1.3 \%$ produced LT and $4.2 \%$ produced VT1 but neither produced ST. We also performed PCR for genes encoding VF. PCR demonstrated that 27 (48.2\%) isolates were positive to estA (Table 1), but not to estB (data not

Table 1 - Primers sequence, annealing temperature and predicted lengths of PCR amplification products.

\begin{tabular}{|c|c|c|c|c|}
\hline Gene & Sequence ( 5 , & Amplicon (bp) & Anneling temperature & References \\
\hline estA & $\begin{array}{l}\text { TCC GTC AAA CAA CAT GAC GC } \\
\text { ATA ACA TCC AGC ACA GGC AC }\end{array}$ & 176 & $50^{\circ} \mathrm{C}$ & BLANCO et al., 1992 \\
\hline stx 1 & $\begin{array}{l}\text { CGC TGA ATG TCA TTC GCT CTG C } \\
\text { CGT GGT ATA GCT ACT GTC ACC }\end{array}$ & 304 & $55^{\circ} \mathrm{C}$ & BLANCO et al., 2003 \\
\hline$s t \times 2$ & $\begin{array}{l}\text { CTT CGG TATA CCT ATT CCC GC } \\
\text { CTG CTG TGA CAG TGA CAA AAC GC }\end{array}$ & 516 & $55^{\circ} \mathrm{C}$ & BLANCO et al., 2003 \\
\hline cnf-s & $\begin{array}{l}\text { CTG GAC TCG AGG TGG TGG } \\
\text { CTC CTG TCA ACC ACA GCC }\end{array}$ & 533 & $63^{\circ} \mathrm{C}$ & BLANCO et al., 1994 \\
\hline F41 & $\begin{array}{l}\text { GGC TAT GGA AGA CTG GAG AGG G } \\
\text { GGG GTG ACT GAG GTC ATC CC }\end{array}$ & 431 & $58^{\circ} \mathrm{C}$ & FIDOCK et al, 1989 \\
\hline F17 & $\begin{array}{l}\text { CTG ATA AGC GAT GGT GTA ATT AAC } \\
\text { GCA GAA AAT TCA ATT TAT CCT TGG }\end{array}$ & 537 & $58^{\circ} \mathrm{C}$ & BERTIN et al, 1996 \\
\hline K99 & $\begin{array}{l}\text { TAT CCA CCA TTA GAC GGA GC } \\
\text { TGG GAC TAC CAA TGC TTC TG }\end{array}$ & 450 & $60^{\circ} \mathrm{C}$ & ROOSENDAAL et al, 1984 \\
\hline hlyA & $\begin{array}{l}\text { AAC AAG GAT AAG CAC TGT TCT GGC T } \\
\text { ACC ATA TAA GCG GTC ATT CCC GTC A }\end{array}$ & 1117 & $63^{\circ} \mathrm{C}$ & YAMAMOTO et al., 1995 \\
\hline
\end{tabular}

Ciência Rural, v.42, n.5, mai, 2012. 
shown), these samples were confirmed by the suckling mice assay. Enterotoxic activity was maintained after heating at $100^{\circ} \mathrm{C}$ for $15 \mathrm{~min}$ (data not shown). Together, the results suggest that 27 isolates are ETEC strains, because they produced ST toxins. The isolates did not harboring $c n f$, st $x 1$, st $x 2, \mathrm{~F} 41$, and K99 genes. URDAHL et al. (2002) described that $\boldsymbol{E}$. coli isolated in sheep carried $s t x 1$ and st $x 2$, different from our results. THEIL et al. (1996), also comment that an important involvement of K99 piliated $\boldsymbol{E}$. coli among other etiologic agents in the lambs diarrhea, however the $27 \boldsymbol{E}$. coli strains in this study did not show adhesive factors associated to ETEC such as K99 and F41. However, CID et al. (1993) studying 627 E. coli isolated from lambs with diarrhea, observed that neither $\boldsymbol{E}$. coli produced adhesins (K99 or F41), but expressed F17 adhesive factor. Interestingly, none of these F17 positive $\boldsymbol{E}$. coli strains produced heat-stable enterotoxin (STa). Although, among our STa positive $\boldsymbol{E}$. coli strains two (2/27) presented the F17 gene (7.4\%) (Table 2). Alpha-hemolysin gene was detected in $44.4 \%$
(12/27) of STa positive samples (Table 2) and presented hemolytic activity at sheep erythrocytes (Table 2). Hemolytic activity can be associated with increased virulence by the greater iron availability or causing toxic effets in host defense cells. This VF is commonly associated with $\boldsymbol{E}$. coli that cause diarrhea in human and animals (BURGOS \& BEUTIN, 2010). Rotavirus can be frequently associated with lamb diarrhea. THEIL et al. (1996) detected rotavirus in $75 \%$ of the diarrheagenic feces from neonatal lamb in the United States. To evaluate the presence of rotavirus in diarrheic feces studied in this study, the nucleic acids were extracted from fecal samples and examined by PAGE (HERRING et al. 1982). The results were negative for detection of rotavirus double-stranded RNA genome in PAGE. This data suggests that this virus is not associated with the lamb diarrhea in these farm, so the $\boldsymbol{E}$. coli strains isolated in this study were the principal causes of lamb diarrhea.

Our data suggest that STa contribute for the colibacillosis development. This outbreak of diarrhea, in

Table 2 - Detection of hlyA and F17 genes and $\alpha$ and $\beta$ hemolysin in STa positive strains and results by suckling mice assay.

\begin{tabular}{|c|c|c|c|c|c|c|}
\hline \multirow{2}{*}{\multicolumn{2}{|c|}{ est $A^{+}$strains }} & \multirow{2}{*}{ hlyA } & \multirow{2}{*}{ F17 } & \multirow[b]{2}{*}{$\alpha$-haemolysin } & \multirow[b]{2}{*}{$\beta$-haemolysin } & \multirow{2}{*}{ Suckling mice assay } \\
\hline & & & & & & \\
\hline \multicolumn{2}{|r|}{6} & + & - & + & - & + \\
\hline \multicolumn{2}{|r|}{14} & - & - & - & - & + \\
\hline \multicolumn{2}{|r|}{19} & - & - & - & - & + \\
\hline \multicolumn{2}{|r|}{20} & - & - & - & - & + \\
\hline \multicolumn{2}{|r|}{21} & + & - & + & - & + \\
\hline \multicolumn{2}{|r|}{22} & + & - & + & - & + \\
\hline \multicolumn{2}{|r|}{23} & - & - & - & - & + \\
\hline \multicolumn{2}{|r|}{24} & - & - & - & - & + \\
\hline \multicolumn{2}{|r|}{25} & + & - & + & - & + \\
\hline \multicolumn{2}{|r|}{30} & - & - & - & - & + \\
\hline \multicolumn{2}{|r|}{31} & - & - & - & - & + \\
\hline \multicolumn{2}{|r|}{32} & - & - & - & - & + \\
\hline \multicolumn{2}{|r|}{34} & - & - & - & - & + \\
\hline \multicolumn{2}{|r|}{35} & - & - & - & - & + \\
\hline \multicolumn{2}{|r|}{36} & + & + & + & - & + \\
\hline \multicolumn{2}{|r|}{37} & - & - & - & - & + \\
\hline \multicolumn{2}{|r|}{40} & + & - & + & - & + \\
\hline \multicolumn{2}{|r|}{41} & - & + & - & - & + \\
\hline \multicolumn{2}{|r|}{42} & + & - & + & - & + \\
\hline \multicolumn{2}{|r|}{47} & - & - & - & - & + \\
\hline \multicolumn{2}{|r|}{48} & - & - & - & - & + \\
\hline \multicolumn{2}{|r|}{49} & - & - & - & - & + \\
\hline \multicolumn{2}{|r|}{50} & + & - & + & - & + \\
\hline \multicolumn{2}{|r|}{54} & + & - & + & - & + \\
\hline \multicolumn{2}{|r|}{56} & + & - & + & - & + \\
\hline & 58 & + & - & + & - & + \\
\hline & 59 & + & - & + & - & + \\
\hline Total & 27 & 12 & 2 & 12 & 0 & 27 \\
\hline
\end{tabular}


São Paulo State, was provoked by type 1 heat-stable enterotoxin (STa). It is the first report of STa production by ETEC isolated from lambs in Brazil. Further studies are necessary to understand the possible role of ETEC and other pathotypes in lamb diarrhea.

\section{ACKNOWLEDGMENTS}

We would like to thank Ana Stella Menegon Degrossoli, who provided technical assistance. This work was supported by grants from Coordenação de Aperfeiçoamento de Pessoal de Nível Superior (CAPES) and Fundação de Amparo à Pesquisa do Estado de São Paulo (FAPESP).

\section{BIOETHICS AND BIOSSECURITY COMMITTE APPROVAL}

The present study was approved by the Ethical Committee on CEUA/UNICAMP, n. 2504-1, and was in accordance with the Ethical Principles in Animal Experimentation (COBEA)

\section{REFERENCES}

BERTIN, Y. et al. Rapid and specific detection of F17-related pilin and adhesion genes in diarrheic and septicemic Escherichia coli strains by multiplex PCR. Journal of Clinical Microbiology, v.34, p.2921-2928, 1996.

BEUTIN, Y.; BURGOS, L. Common origin of plasmid encoded alpha-hemolysin genes in Escherichia coli. BMC. Microbiology, v.10, p.193, 2010. Available from: <http:// www.biomedcentral.com/1471-2180/10/193>. Accessed: Jul. 29, 2011. doi. 10.1186/1471-2180-10-193.

BLANCO, J. et al. Serogroups of Escherichia coli strains producing cytotoxic necrotizing factors CNF1 and CNF2. FEMS Microbiology Letters, v.96, p.155-159, 1992. Available from: $<$ http://www.sciencedirect.com/science/article/pii/ 0378109792903966>. Accessed: Jan. 22, 2012. doi. 10.1016/ 0378-1097(92)90396-6.

BLANCO, M. et al. Genes coding for Shiga-like toxins in bovine Verotoxin-producing Escherichia coli (VTEC) strains belonging to different $\mathrm{O}: \mathrm{K}: \mathrm{H}$ serotypes. Veterinary Microbiology, v.42, p.105-110, 1994. Available from: <http://www.sciencedirect.com science/article/pii/0378113594900108>. Accessed: Jul. 29, 2011 doi. 10.1016/0378-1135(94)90010-8.

BLANCO, J. et al. Serogroups, toxins and antibiotic resistance of Escherichia coli strains isolated from diarrhoeic lambs in Spain. Veterinary Microbiology, v.49, p.209-217, 1996. Available from: <http://www.sciencedirect.com/science/article/pii/ 0378113595001883>. Accessed: Jul. 29, 2011. doi. 10.1016 0378-1135(95)00188-3.

BLANCO, M. et al. Serotypes, virulence genes, and intimin types of Shiga toxin (Verotoxin)-producing Escherichia coli isolates from healthy sheep in Spain. Journal of Clinical Microbiology, v.41, p.1351-1356, 2003. Available from: <http:/ /jcm.asm.org/cgi/reprint/41/4/1351>. Accessed: Jul. 29, 2011. doi. 10.1128/JCM.41.4.1351-1356.200.

CID, D. et al. F17 fimbriae in Escherichia coli from lambs and kids. Veterinary Research, v.132, p.251, 1993.
DEAN, AG. et al. Test for Escherichia coli enterotoxin using infant mice: application in a study of diarrhea in children in Honolulu. Journal of Infectious Diseases, v.124, p.407411, 1972. Available from: <http://jid.oxfordjournals.org/content/ 125/4/407.short>. Accessed: Jul. 26, 2011. doi. 10.1093/infdis/ 125.4 .40 .

FIDOCK, DA. et al. Nucleotide sequence of the F41 fimbriae subunit gene in Escherichia coli B41. Nucleic Acids Research, v. 17, p. $2849,1989$.

HERRING, AJ. et al. Rapid diagnosis of rotavirus infection by direct detection of viral nucleic acid in silver stained polyacrylamide gels. Journal of Clinical Microbiology, v.16, p.473-477, 1982. Available from: < http://jcm.asm.org/cgi/ reprint/16/3/473>. Accessed: Jul. 27, 2011.

ROOSENDAAL, B.et al. The nucleotide sequence of the gene encoding the K99 subunit of enterotoxigenic Escherichia coli. FEMS Microbiology Letters, v.22, p.253-258, 1984.

SMITH, HW.; HUGGINS, MB. Effectiveness of phages in treating experimental Escherichia coli diarrhoea in calves, piglets and lambs. Journal of General Microbiology, v.129, p.26592675, 1983. Available from: <http://mic.sgmjournals.org/content/ 129/8/2659.full.pdf + html>. Accessed: Jul. 26, 2011. doi. 10.1099/00221287-129-8-2659.

THEIL, KW. et al. Rotaviruses associated with neonatal lamb diarrhea in two wyoming shed-lambing operations. Journal of Veterinary Diagnostic Investigation, v.8, p.245-248, 1996. Available from: <http://vdi.sagepub.com/content/8/2/ 245.full.pdf $>$. Accessed: Jul. 27, 2011. doi. 10.1177/ 104063879600800217

TOLEDO, MR. et al. MILi - um meio para a realizacao dos testes de motilidade, indol e lisina descarboxilase. Revista de Microbiologia, v.13, p.230-235, 1982a.

TOLEDO, MR. et al. EPM - Modificação do meio de Rugai e Araujo para a realização simultânea dos testes de produção de gás a partir da glicose, $\mathrm{H}_{2} \mathrm{~S}$, urease e triptofano desaminase. Revista de Microbiologia, v.13, p.309-315, 1982b.

URDAHL, AM. et al. Serotypes and virulence factors of Shiga toxin-producing Escherichia coli isolated from healthy Norwegian sheep. Journal of Applied Microbiology, v.93, p.1026-1033, 2002. Available from: <http:// onlinelibrary.wiley.com/doi/10.1046/j.1365-2672.2002.01787.x/ pdf $>$. Accessed: Jul. 26, 2011. doi. 10.1046/j.13652672.2002.01787.x

VETTORATO, MP. et al. Properties of Shiga toxin-producing Escherichia coli (STEC) isolates from sheep in the State of São Paulo, Brazil. Veterinary Microbiology, v.95, p.103-109, 2003. Available from: $<$ http://www.sciencedirect.com/science/article/pii/ S0378113503001536>. Accessed: Jul. 26, 2011. doi. 10.1016/ S0378-1135(03)00153-6.

YAMAMOTO, S. et al. Detection of urovirulence factors in Escherichia coli by multiplex polymerase chain reaction. FEMS Immunology and Medical Microbiology, v.12, p.85-90, 1995. Available from: <http://www.sciencedirect.com/science/ article/pii/092882449500053A $>$. Accessed: Jul. 29, 2011. doi. 10.1016/0928-8244(95)00053-A 